\title{
Gender and Generation in Household Labor Supply in Jordan
}

\author{
Mary Kawar*
}

* Mary Kawar currently works as the gender and women specialist at the International Labor Organization (ILO) Regional Office in Beirut, Lebanon.

Funds for the publication of this paper from the Andrew W. Mellon Foundation are acknowledged.

\section{Preface}

The Youth Working Group Initiative represents a joint effort of the MEAwards Program in Population and the Social Sciences (MEAwards) of the Population Council's Regional Office for West Asia and North Africa, and the Social Research Center of the American University in Cairo. Among the priority goals of the two institutions is strengthening cooperation within countries of the region on population research, contributing to scholarly debates and capacity building, and providing input for better policy formulation. This collaboration is a special activity of the project on "The New Arab Demography" at SRC/AUC sponsored by the Andrew W. Mellon Foundation. The New Arab Demography Project is a regional collaborative research 
activity that focuses on new patterns of demographic change as well as new policy concerns in the Arab region.

The Middle East region is experiencing unprecedented growth of its youth population, and yet this remains the most understudied group in the population. The Youth Working Group initiative aims at creating an ongoing forum for regional researchers to engage in dialogue and studies on youth, with an emphasis on both cross country and multidisciplinary research. Towards this goal, a first study group meeting was held in Cairo on November 19-20, 1998 with the participation of sixteen researchers from Algeria, Egypt, Jordan, Palestine, Sudan and Turkey. They addressed a number of important issues related to youth, including identity, livelihoods, generations and the re-structuring of age-gender roles, youth and the demographic transition, as well as health and risks associated with this stage of life. The paper by Mary Kawar was originally presented in that meeting, and stimulated lively discussion around the transitions of youth to adult livelihoods.

Dr. Seteney Shami, former director of the MEAwards program played a vital role in initiating early activities of the group. Under the coordination of Dr. Sahar el-Tawila of SRC/AUC, a working group meeting of researchers interested in youth health issues was held in 1999, and a newsletter to keep the working group informed of ongoing activities will begin circulating early in 2000. These and other activities are designed to enhance regional dialogue on youth issues and encourage significant research initiatives. The collaborating institutions believe in the importance of this work and the ability of youth to contribute positively to demographic and social change in the region.

Hoda Rashad, Ph.D.

Ibrahim Elnur, D. Phil.

Research Professor and Director

Director

Social Research Center

MEAwards Program

American University in Cairo

The Population Council

Cairo

April 2000

\section{Acknowledgments}

This paper is part of a Ph.D research project completed in 1997. As such, I would like to start by extending my gratitude to Dr. Sylvia Chant, my supervisor at the London School of Economics, for her invaluable support and patience throughout the research process.

The research upon which this paper is based was generously funded by a grant to undertake my dissertation fieldwork from the MEAwards Program of the Population Council's West Asia and North Africa Office in Cairo. The comments I received from the MEAwards staff on my research proposal helped give direction to the research. I am also grateful to individuals at the Population Council who have been a source of encouragement and support throughout my career. I wish to mention Ms. Moushira 
Elgeziri, Dr. Seteney Shami and Dr. Barbara Ibrahim. Their support is inspired by their commitment to the advancement of population and social science research in the Middle East.

The views expressed in this paper are my own and do not reflect the views of the ILO.

\begin{abstract}
This paper examines both gender and age differences in the labor supply of households in Jordan, as well as the impact of young women's employment on gender and generation relations. The objective of the study is to address the issues of gender and generation as factors influencing accessibility to labor markets, and to provide a broader understanding of female employment by exploring age-related factors.

Empirically, the study looks at the disproportionate workforce participation of young urban single women in Amman, Jordan, and argues that this generation of working women is evidence of a new stage in the lives of Jordanian women: single employed adulthood. In other words it looks at a specific "time" in the social and economic lives of households and individuals. Within this context, the paper attempts to construct a profile of employment characteristics of adult household members in order to explore the intersecting influences of age and gender and the specific positions of young women. It then addresses how normative gender and generation hierarchies within households respond to these phenomena of young women's work, their prolonged single status and their expanding horizons.

In many ways, Jordanian households are experiencing changes in demographic structures, internal organization and economic balance. These factors heavily influence family ideologies and the behavior of individuals. Adult single working women seem to be at the centre of these changes, where they must negotiate new realities.
\end{abstract}

\title{
Table of Contents
}

$\begin{array}{llc}\text { I } & \text { Introduction } & \text { Page } \\ \text { II } & \text { Research methodology } & 1 \\ \text { III } & \begin{array}{l}\text { Employment characteristics of } \\ \text { household members }\end{array} & 2 \\ & & 3 \\ \text { IV } \quad \text { Household factors affecting young } & 7 \\ & \quad \text { women's employment } & 12 \\ \text { V } \quad \text { Impact of young women's employment }\end{array}$


on gender and generation relations

VI Conclusion $\quad 21$

References $\quad 23$

Endnotes $\quad 25$

\section{Introduction}

At 14 percent, female labor force participation rates in Jordan are relatively low compared to other regions in the world. However, one significant characteristic is a disproportionate presence of young women workers. Possibly as a result of the young age structure of the population in general, as many as 68 percent of female workers are less than 30 years old (compared to 50 percent of males). Increasing education levels and more diverse employment opportunities as a result of technological change and expansion of manufacturing account for this phenomenon, as well as the increasing age at which women marry: an average of 17.3 years in 1971, rising to 24.6 years in 1995.

Traditionally, Jordanian society has been based on rigid gender and generation hierarchies, with a woman's roles and identities restricted to those of child, adolescent, and then dependent wife and mother. This paper argues that the increasing visibility of young single women workers is evidence of a new stage in the lives of many Jordanian women: single employed adulthood. This study explores whether this is leading to changes in normative gender and generation hierarchies within the household. Indeed, the paper illustrates that Jordanian households are effectively passing through a stage where demographic changes are affecting the internal structure, organization, and economic balance of the family on the one hand, and family ideologies and the behavior of individuals on the other.

We pose three questions:

1. With the current structure of the Jordanian population, which household members are working? We investigate the individual characteristics of working-age household members, including employment status, education levels, occupations, and wages.

2. What household factors affect daughters' employment? We address household-level characteristics linked to female employment, such as household size, structure, and income.

3. What is the impact of young women's employment on gender and generation relations? We examine the implications of single employed adulthood and how gender and generation relations are manifested and negotiated.

\section{Research Methodology}


The study utilized both qualitative and quantitative tools. Quantitative research helps us see patterns, and qualitative in-depth research provides insight into some of the reasons behind these patterns. Using a questionnaire, a quantitative survey was administered in face-to-face interviews with members of 302 households in 14 locations across the city of Amman. The sample was drawn by random sorting of households previously visited in the national-level Employment, Unemployment, and Poverty Survey conducted in 1991. The questionnaire was administered to working and non-working women between 20 and 30 years of age who were single and not enrolled in educational programs at the time of the interview. In addition, 40 households from this survey were revisited for more in-depth semi-structured interviews with young women and, depending on household circumstances, other family members. The interviews explored family relations, income distribution and management, life and work history, social activity, and views on marriage and work.

The following analysis is influenced by the fact that it discusses households containing single adult women who are not enrolled in educational programs. It is also limited to a specific stage in the households' life cycles. In many ways, this stage is not representative of Jordanian households as a whole or indeed female workforce participation as a whole. The analysis simply looks at a phenomenon at a specific "time" in the social and economic lives of households and individuals.

Indeed, the focus of this research on a specific "time" in individuals' and households' life courses provides an opportunity to enlarge our understanding of the interdependent trajectories of men and women and consequently draws heavily on gender ideologies (Oakley 1987). For example, men's and women's transitions from one life stage to the next are affected, controlled, and/or legitimized by societal norms and agencies. In this context, the present research chose to focus on a group of women who are in a previously non-existent life-course trajectory that is more a result of economic and demographic change rather than ideological change.

\section{Employment characteristics of household members}

The quantitative aspect of the study provides a gender and age breakdown of the employment characteristics of household members.

\section{Different generations in the household labor supply}

According to Figure 1, the age-specific economic participation of both male and female respondents reveals that the majority are between the ages of 20 and 30 years. Economic participation of men substantially decreases but is still apparent among older age groups. In contrast, economic participation of women is virtually non-existent after the age of 30 years. ${ }^{1}$ 
This distribution, however, is largely determined by the nature of this study, which targeted households with adult daughters and sons. As a result, it also reflects the decreasing activity of older men due to age or retirement and the relative absence of household members between the ages of 30 and 40 years.

\section{Figure 1. Age specific economic participation of male and female household members}

The difference between older and younger women's economic participation is significant. Although this could be partially due to the fact that younger women are more likely to work than older women (i.e. the life-cycle phenomenon), it is a fact that daughters are not marrying as early as their mothers did and are much more likely to join the labor force. This raises the much-discussed question of the relation between female employment and increasing age at marriage. Indeed, the workforce participation of young women peaks at 24 years and then gradually drops until 30 years. It is probably not coincidental that 24 years happens to be the average age at marriage for females in Jordan, which also indicates that a number of young women drop out of the labor force at this age.

\section{Different education levels of household members}

It is not surprising that adult daughters and sons have higher education levels than their parents. In the last 20 years, education, accompanied by a diminishing gender gap in schooling, has been one of Jordan's main developmental achievements. ${ }^{2}$

For more information on changes in education levels and bridging differences between males and females see Women and Men in Jordan: A Statistical Portrait (Department of Statistics 1999). Indeed, in the household survey, illiteracy is almost non-existent among daughters and sons while it is 11 percent for fathers and as high as 35 percent for mothers. Furthermore, the substantial difference between daughters' and mothers' levels of education signifies a major transition in gender disparities. What is even more significant is that within the same generation, daughters have higher education levels than sons and hence the highest education levels within their households. In the sample survey as many as 82 percent of daughters have a secondary education and above, compared to 68 percent of sons.

\section{Different occupations for household members}

Within any household, members are likely to be distributed throughout different sectors of the labor market. But what are the gender and age divisions between public/private and formal/informal sectors?

Table 1 reveals that more sons and daughters hold public-sector jobs than their parents, possibly because in the sample selected, many parents, especially fathers, have already retired from the public sector. However, there are stark differences between the publicsector employment of the sexes. Young men are mostly in the military, which does not 
require high education, and young women work as professionals, most often as teachers.

In the private sector, differences between those who work as employees or employers provide a key point for exploring gender differences. According to Table 1, a higher proportion of sons and daughters are employees (49 percent and 62 percent, respectively) than fathers and mothers ( 39 percent and 36 percent, respectively). These differences are clearly a function of age, as sons and daughters, because of their youth, are more likely to be employees than their parents. Table 1 also reveals that the highest proportions of employers, that is, people who own their business, are fathers (27 percent), followed by sons (12 percent). In comparison, no mothers and only 3 percent of daughters are employers.

Table 1. Work status of economically active family members

\section{Work Status Daughter(\%)}

$\begin{array}{lcccl}\text { Public-sector employee } & 12(20)^{\mathrm{a}} & 14(2) & 21(43) & 20(50) \\ \text { Private-sector employee } & 39(67) & 36(5) & 49(101) & 62(155) \\ \text { Private-sector employer } & 27(45) & - & 12(24) & 3(7) \\ \text { Self-employed/informal sector } & 22(38) & 50(7) & 15(31) & 11(28) \\ \text { Trainee/unpaid worker } & - & - & 3(6) & 4(9) \\ \text { Total } & 100(170) & 100(14) & 100(205) & 100(249)\end{array}$

Father(\%) Mother (\%) Son(\%)
Source: Household survey.

${ }^{\mathrm{a}}$ Absolute numbers are in parentheses.

In other words, men are more likely to set up their own business than women, and are encouraged to do so, sometimes even utilizing scarce family resources. On the other hand, old and young women are rarely encouraged to start their own business. In addition, very few women have independent resources for any potential venture, and any resources they do possess are usually used for a family project that is controlled by the men.

A substantial proportion of household members are self-employed and in the informal sector. As many as 50 percent of working mothers and 22 percent of working fathers are self-employed, but the number of self-employed sons and daughters is significantly less. This is a clear function of age, as less-educated parents are more likely to engage in informal-sector activities as compared to the younger generation, who tend to be better

educated and working in the formal modern sector. For women, the nature of informal activity seems to be linked with age. Older women and a minority of younger women 
engage in home-based activities, such as sewing and food production, or have jobs outside the home, such as domestic service. A substantial number of home-based selfemployed young women, however, engage in work such as typing, translating, or private tutoring for school children. In comparison, there is no real difference between self-employment opportunities for men of all ages. Activities for younger and older men alike range from petty trade and services to casual labor in construction or manufacturing.

\section{Different earnings of household members}

Given that young women have the highest education levels and are most likely to be in professional occupations, one would expect higher levels of earnings. The opposite is true, however. The average monthly earnings for men are 168 JD (US\$235) compared to average monthly earnings of 105 JD (US\$147) for women. The gap is notably wider than the official statistics for 1994 where the average monthly wage for men was 195 JD (US\$273) compared to 157 JD (US\$220) for women. One justification for this deviation from official data is the inclusion of the informal sector, which is usually not quantified by official statistics. $^{3}$

Within households, mothers and daughters earn the least, sons earn more, and fathers earn the most. As many as 71 percent of mothers and 54 percent of daughters earn less than 100 JD (US\$147) per month. Most fathers and sons, on the other hand, earn between 100 and 299 JD (US\$418). In other words, despite the clear similarities in age between brothers and sisters and the clear differences between mothers and daughters, earning levels seem to be determined by gender.

The household survey data indicate that daughters possess the highest human capital in terms of skill and education and are most involved in the formal modern sector. With work differences between mothers and daughters more salient than those between fathers and sons, perhaps the only common denominator between mothers and daughters is their weak earning power.

\section{Household factors affecting young women's employment}

Household-level characteristics that shape young female labor supply include household size, composition, and income, which have been considered in other studies to explain women's entry into labor markets (Stichter 1990).

\section{Household size and dependency ratios}

Household size in the study sample is comparatively large. The average size is 7.9 persons (Table 2). Given that the economic participation rate of the entire sample is only 32 percent, this means there is a relatively high dependency ratio of 1:3.1 (i.e. 1 worker per 3.1 non-earners). 
Twenty-four percent of the sample population are 15 years old or less (only 5.5 percent of the sample population are 60 years old or older). The high dependency ratio is largely a result of the large family size and the number of small children within it. This might seem to contradict the fact that this study focuses on households in the advanced stages of the domestic cycle with adult children of working age. Two decades ago, however, the age at marriage for women was low, meaning that women had children over a long period of time. The existence of adult working children does not mean that there are no young children present.

Table 2. Mean household size, number of income earners, and dependency ratio, by young women's work status

$\begin{array}{lllll}\begin{array}{l}\text { Employment } \\ \text { Status of } \\ \text { Daughter }\end{array} & \begin{array}{l}\text { Average } \\ \text { Household } \\ \text { Size }\end{array} & \begin{array}{l}\text { Number of } \\ \text { Workers }\end{array} & \begin{array}{l}\text { Number of } \\ \text { Young } \\ \text { Women } \\ \text { Respondents }\end{array} & \begin{array}{l}\text { Dependency } \\ \text { Ratio } \\ \text { (workers } \\ \text { per non } \\ \text {-earner) }\end{array} \\ \text { Employed } & 7.4 & 504 & 249 & 1: 2.9 \\ \text { Unemployed } & 8.1 & 205 & 102 & 1: 3.1 \\ \text { Inactive } & 8.4 & 61 & 51 & 1: 3.3 \\ \text { Total } & 7.9 & 77 & 402 & 1: 3.1\end{array}$

Source: Household survey.

The household survey in Amman reveals that the labor force participation of young single women is higher among smaller households. ${ }^{4}$ In contrast, unemployed and inactive young women belong to larger households (Table 2). Consequently, the dependency ratio in households of employed women is less than that in households with either unemployed or inactive women. However, women with different employment status may belong to the same household (i.e. sisters). Therefore, household size alone is not clearly indicative of all factors that influence the household labor supply of young women.

\section{Household composition}

Of the total sample survey, 78 percent of households are nuclear units headed by a man (Table 3). In terms of the extended households, a majority of these consist of married sons and their respective families. It is common for sons in Jordan to start their married lives with their families. Some of these sons, however, eventually separate from their natal households.

Table 3. Distribution of households according to family types

\section{Household Type \%}

Nuclear 


$\begin{array}{ll}\text { Male-headed } & 78(236)^{\mathrm{a}} \\ \text { Female-headed }^{\mathrm{b}} & 4(12) \\ \text { Elder son-headed } & 1(4) \\ \text { Extended }^{\mathrm{c}} & \\ \text { Polygamous } & 1(2) \\ \text { Married sons } & 10(31) \\ \text { Relatives (grandparents, uncles, etc.) } & 1(2) \\ \text { Married sons and relatives } & 5(15) \\ \text { Total } & 100(302) \\ \text { Source: Household survey. } & \\ \text { a Absolute numbers are in parentheses. } & \\ \mathrm{b}_{\text {Mother-headed except for two families headed by daughters. }} \\ { }^{\mathrm{c}} \text { All extended households are male-headed except for one case where a married son } \\ \text { lives with his mother. }\end{array}$

Only 4 percent of the survey sample could be described as female-headed households. This is even lower than national-level statistics, which in 1991 estimated femaleheaded households at 6.4 percent. Female heads of households are mostly widows or wives of male migrant workers in the Arab Gulf region. ${ }^{5}$ Until the mid-1980s outmigration of men to oil-rich Gulf states was significant, which caused an increase in de facto female-headed households during that period. For example, a 1986 study in Amman revealed that 12 percent of households were headed by females (see Bisharat and Zagha 1986). However, as a result of the recession and the 1990 Gulf war, work opportunities for men decreased, and many were repatriated, thus reducing the number of female-headed households. Desertion by husbands and single motherhood are rare in Jordan. In addition, it is not uncommon for divorced women to return to their natal homes and for widowed women to live with their husband's kin (see Sawalha 1993 for a discussion). Also, young women and men, irrespective of income levels, never set up a home on their own before marriage, so that there are almost no single-person households.

The prevalence of nuclear household forms in Amman, therefore, contradicts general assumptions that describe the Arab family as extended and dependent on kin relations. If we are to accept the fact, however, that in Amman there is a broadly linear transition from extended to nuclear household forms, it is not inconceivable that the increasing workforce participation of young women is a response to a situation in which extended households characterized by a greater number of male income earners are in decline. ${ }^{6}$ In terms of social history, there is little evidence that documents the previous prevalence of extended household forms as compared to nuclear forms in present day Amman. The speculation here is based on the household survey results as compared to traditional notions that describe households. It is also derived from parents' descriptions of their living arrangements in the past, many of whom lived in rural areas 
(i.e. before urbanization). In addition, evidence suggesting that this transition towards nuclear households is likely to continue came from the women respondents. During discussions of future marriage prospects many women stated their desire for a future husband who has his own home. Living in an extended household is generally not desired by young women today. In other words, changing household structure is resulting in a reorganization of labor arrangements. Income earning is currently distributed among members of the nuclear family irrespective of gender, while previously (i.e. in extended households) it was distributed among male family members only.

In addition, attempts to categorize households into specific forms (nuclear, extended, female-headed, or single) often overlap with identifying a household head, who is usually assumed to be the main breadwinner and decision-maker (see also Chant, 1991). Household headship, which revolves around a patriarchal ideology, assumes that fathers are the "natural" source of authority. The young women surveyed in Amman stated that the eldest brother was the household head when the father was not present. The eldest brother was identified as the head of the household even when the mother was present, when the sister was older in age, or when the brother was not an income earner. In other words, the ideology of the male head of household is resilient even when circumstances might challenge it. An illustration of this is one household where the father was deceased and the mother was economically inactive. The two sons were unemployed and a daughter was the only member of the family with a stable income. The head of the household was identified as the elder of the two sons even though the working daughter was older. Gender considerations, as a result of patriarchal ideology, eclipse age considerations (i.e. the presence of the mother and the age of the working daughter).

To a large extent, the ideology of the male head extends beyond the physical confines of households. Household organization in Amman may be increasingly nuclear, but the symbolism and social relations that revolve around the extended family are still prevalent (Shami and Taminian 1989: 44). Because of the primacy of kin relations, therefore, there are fluid boundaries between households, and the term "head of family" has greater relevance than "head of household" in Jordan. Married sons, for example, who move out of their parents' homes often live in adjacent dwellings (Shami and Taminian 1989: 44). So although a married son has a separate living unit, the actual head of the family is his father. Furthermore, in many areas in Amman extended kin groups live in the same vicinity. Within these kin groups there is always a male elder to whom individuals in different living units defer for decisions and problem solving.

Therefore, it could be said that in terms of household structure two conflicting forces affect the supply of young female labor. The first is the decreasing numbers of male 
income earners in nuclear households, which pushes young women into the labor force. The second is the persistence of the ideology of extended family networks, which puts constraints on the supply of female labor.

\section{Household income}

The effects of household income on women's employment has been addressed extensively in the literature. On the whole, empirical evidence suggests that the lower the household income, the greater women's economic participation (Bruce and Dwyer 1988; Chant 1991; Stichter 1990). Perhaps because of this, many studies look at the relationship between women's workforce participation and household incomes within low-income households. In the context of young women's participation in Amman, however, this relationship does not apply. Indeed, there is significant workforce participation among women in middle- and upper-income households.

According to Table 4 the mean annual income of households with working daughters is significantly higher than that of households with either unemployed or inactive daughters. There are two possible and mutually reinforcing explanations for this. The first is that women from higher income and socioeconomic backgrounds are more likely to work, possibly as a result of higher education and better employment opportunities. The second is that the involvement of young women in paid work generates higher levels of overall family income.

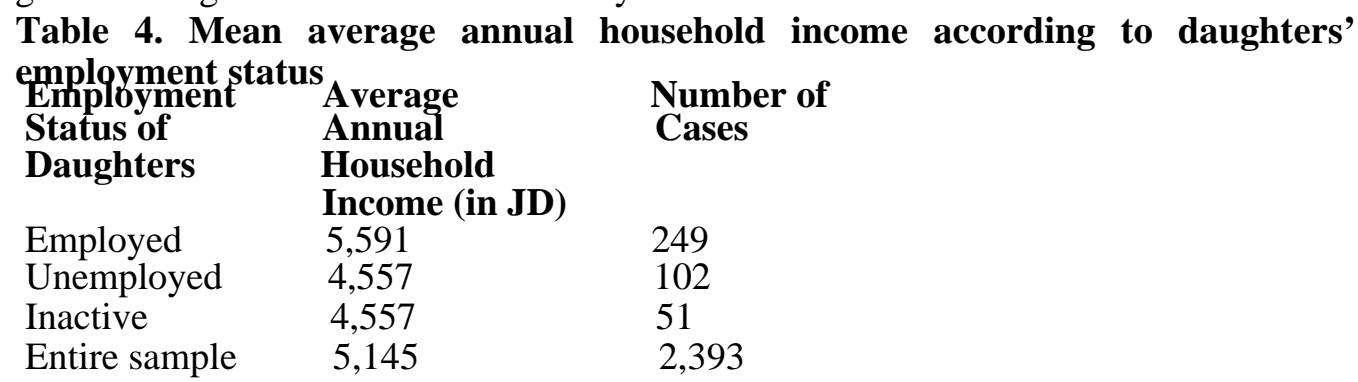

Source: Household survey.

Indeed, it is difficult to ascertain the precise relation between household income and the labor supply of daughters in Amman. This is because in some cases sisters in the same household may have different employment status, slightly altering the data presented in Table 4, which calculated household income according to number of respondents. Second, young women's wages tend to be low irrespective of the overall household income. The majority of working women, 90 percent $(n=225)$, earn less than 200 JD (US\$296) per

month irrespective of their household income. In contrast, males from households with higher income levels usually earn higher wages. ${ }^{7}$ Therfore, the overall impact of daughters' wages on household income is not significant. 
Class position also influences female employment. The idea of class differentiation encompasses more than mere differences in income levels between households; it also includes education level of head, area of residence, type of work of head, level of urbanization, and so on. In Amman, class position affects household attitudes towards female employment, and consequently female labor supply, more than does household income per se. Restrictions on female employment seem to be much stronger among those whose class positions are considered lower. Despite women's low earnings, the necessity for their contributions is perhaps threatening to the dominant male breadwinner ideology.

\section{Impact of young women's employment on gender and generation relations}

The qualitative portion of the study explored how changing trends in the female labor supply affect family relations.

Our results suggest that a reconstruction of gender and generation relations is underway in Amman, a result of crosscurrents between normative gender relations and young women's new life stage. These crosscurrents include, on the one hand, household concessions that expand young women's opportunities in education, employment, and marriage options, and, on the other hand, notions of family honor (i.e. preserving young women's sexual reputation), which have been brought to the fore as a result of expanding opportunities.

To illustrate these crosscurrents we examine a range of issues. Some reveal that young women's employment is resulting in new expectations and conditions that are, in effect, new forms of control. On the other hand, some state that traditional values concerning family honor are being reinstated. Ultimately both of these result in the reconstruction of normative family relations. Relevant issues include the relation between education and employment, acceptable types and conditions of work, sexual harassment at work, family honor, and young women's public behavior.

\section{Education and employment}

The positive relationship between higher female education and increasing rates of employment has been already established. What remains to be addressed is whether young women freely choose their areas of higher education or whether education type is conditional upon accepted gender roles; how aware families are of the linkages between higher education and future employment; and freedom of young women to choose employment type after finishing their education.

Most parents take a more or less egalitarian attitude towards promoting sons' and daughters' basic education, with the rationale that it is their duty in fulfilling their roles as good parents. ${ }^{8}$ Our respondents are the first generation of beneficiaries of the 
education policies of Jordan that provide equal education to all as well as subsidized college and university education. However, after basic schooling, choices for young women who plan to continue higher education are filtered through their families. The rationale for giving girls education may be different from that for boys and, as a result, parents will seek to influence the type of education a daughter may acquire while sons are encouraged to choose for themselves.

In the sample survey, higher education of daughters was linked to prestige across all income groups. Employment, on the other hand, was not. On the whole, women are encouraged to embark on studies in keeping with their gender roles, primarily teaching skills, which include a "mothering" element and tend to entail sex-segregated working environments. As a result, many young women enroll in teacher training programs.

In other situations, young women insist on studying disciplines that are considered problematic by parents in terms of ascribed gender roles. In such cases young women are usually allowed to continue with their studies. However, when it comes to finding employment all sorts of restrictions and obstacles are put forward. To illustrate parents' contradictory attitudes towards education and employment of girls, the remainder of this section discusses some of the restrictions imposed.

Young women at times are categorically denied access to employment after completing their education or training, one case being a nurse who after obtaining her degree and training was forbidden by her father to work in an environment where she would be in

constant contact with male patients and co-workers. Another case was a woman who was encouraged to pursue training to become a mechanic through a governmentsponsored training scheme. Later she was not allowed to seek employment, as her skill was considered a "male" job and therefore inappropriate for a young woman. In both cases the parents were proud of their daughters' achievements despite the fact that the women remained unemployed.

Young women who complete higher levels of education often encounter parental conditions that make it impossible for them to find employment. For example, they are expected to find employment in a single-sex environment close to where they live, working hours that will guarantee they are home before dark. Another set of restrictions is related to a very narrow view of educational attainment. An example is a young woman who had a two-year degree in finance. According to her parents she could work only in a bank, which is viewed as a respectable working environment. This young woman had many offers to work as an assistant accountant in private-sector firms; however, this was prohibited by her parents who saw small firms as areas of potential risk for their daughter's reputation.

A variety of restrictions are put on women looking for employment even though these are minimal when girls embark on education. Indeed, this is one of the perplexing 
crosscurrents in parents', and particularly fathers', behavior regarding young women's single adulthood. Higher education is regarded in a positive light, even if it means daughters will interact with men and live away from home. Employment, on the other hand, is regarded as a potential threat to the traditional norms that encourage sex segregation and control of female autonomy. The problem with these crosscurrents, however, is that higher education exposes young women to new ideas, different ways of life, and social freedom. It also nurtures aspirations for economic and social independence. This exposure changes the attitudes and life expectations of the young women, so that when parents impose restrictions on employment, the young women become resentful, which may result in family friction.

Acceptable types and conditions of work

The overarching concern of most parents is the preservation of young women's chastity and social reputation. Conditions for acceptable employment for young women in Amman,

Therefore, include gender segregation at work and what parents consider a "respectable" working environment.

A predominant concern among many families is that a daughter should be home before dark (which might be as early as five o'clock in the winter). There is general agreement that the workday should be finished by early evening; any woman who is not home by then draws suspicion to her behavior. In general, women working as teachers do not face such problems, as school days are short. Beside the fact that teaching is considered a respectable female job, the short working hours provide another incentive. Most manufacturing industries and workshops that employ young women also have reasonable working hours. Employers are aware of the restrictions on women working in the evenings, so they schedule daylight working hours for their female employees.

Families also restrict where they will allow their daughters to work. Social restrictions on women's movement result in some parents not allowing their daughters to utilize public transportation, which has a predominantly male ridership. However, there are solutions to this obstacle. For example, if a well-known establishment employs several women from the same community, the young women who commute together daily can monitor one another. In addition, they will tend not to be harassed by strangers because they are in a group; and because more than one woman is commuting, it will be hard for the larger community to disapprove of their employment in a distant part of the city.

Another restriction is that families feel they should know their daughter's employer. Where possible, daughters work for relatives, family friends, or neighbors. If an employer is unknown, the family will make inquiries about him to ascertain his "reputation" (his attitude towards and treatment of women workers). When a young woman finds work, sometimes her brother or father will accompany her to finalize the conditions of her employment and meet the employer face to face. Sometimes a father 
will state explicitly "I am entrusting you with my daughter" and the employer will answer, "Do not worry. She will be like my own daughter as long as she is working here".

Employers have two strategies to accommodate family restrictions on female mobility: (1) Those who depend on young female labor set up their business in proximity to labor supply, usually near congested low-income neighborhoods, where women who need to

work reside; ${ }^{9}$ and (2) large manufacturing employers provide transportation for their female workers, as such large factories are often located on the outskirts of the city, far from residential areas.

Many families find the working conditions unacceptable in small private-sector establishments. The working hours are longer; employers do not provide concessions for female labor, such as transportation or daylight working hours; and very few private-sector firms have sex-segregated workspaces.

A secretarial job, in particular, is regarded by many as unacceptable, as it entails working for a male boss and exposing oneself to possible sexual harassment. Families are most comfortable when a daughter works at a school, bank, or in the public sector, because everyone knows where and whom she works for, and this knowledge protects the daughter's public image and sexual reputation. In contrast, because it is more difficult for parents to ensure the good reputation of a small, unknown, private-sector firm, many are hesitant to allow their daughters to work in such establishments.

A substantial number of young women in Amman nevertheless work in small, privatesector establishments. Within such firms the general attitude of employers is that young women are rarely ready to put in the working hours involved. Employers generally assume that women are not motivated to work. Few employers realize that working hours suit men's work patterns and are actually problematic for young women and virtually impossible for married women. Employees of private-sector establishments in Amman generally work a morning shift from eight o'clock to one o'clock in the afternoon with a two- to three-hour lunch break, followed by an afternoon shift from three or four o'clock to six o'clock in the evening or later. Weekends are usually one to one-and-a-half days long. This schedule tends to be problematic for young women, especially those who are in administrative, sales, or secretarial positions. The long lunch breaks are actually devised for married men who go home to eat lunch and take a siesta and for younger, unmarried men, who are more socially mobile. Because young women's wages are often less than those of men, women usually do not own a car, nor are they able to afford extra trips on public transport to go home for lunch. Young women are also less likely to go to restaurants or to entertain themselves during the lunch break, both because of the cost and because it is not common for young women to be in public places on a daily basis. The result is that they stay at their desks during the long lunch break and are effectively at work for 10 hours a day, six days a week. 
Because such hours leave young women with little private time, many become dissatisfied. Indeed, even the most ambitious young women report being disenchanted, unmotivated, and on the lookout for better opportunities. The consequent high turnover rates tend to marginalize them in such private-sector establishments and reinforce employers' stereotyped assumptions about female labor.

\section{Sexual harassment and gender ideology}

Many of the aforementioned restrictions put on the conditions of young women's work are a means of preserving women's sexual reputations. Within this context it is important to know the extent to which employment exposes young women to sexual harassment. It is also important to know whether this control of female sexuality acts as a deterrent to sexual harassment at the workplace.

In a socially restricted society such as Jordan, any subject pertaining to sexuality is taboo, which makes the issue of sexual harassment difficult to address. Young women may not be aware of what constitutes sexual harassment, ${ }^{10}$ and even those who are exposed to outright harassment may not admit to it because they fear that they will lose their jobs or that their parents will permanently withdraw them from employment; women also fear their sexual reputations may be damaged. As for those young women who are aware of and ready to discuss the issue of sexual harassment, there is general agreement that it can only occur if women invite it. However, the following discussion reveals that the issue is not sexual harassment as much as it is the preoccupation with preventing it.

In some ways, all male employers are perceived as potential threats to the reputations of female employees in their charge. As a result, any employer who needs female labor has to prove his innocence to the young women themselves as well as to their families. On occasion the wife of the employer works as the general supervisor in small workshops staffed exclusively by women. The wife's presence helps ensure that the working environment and any interaction with the male employer is comfortable.

Many employers want to be perceived as father figures in order to discourage women from seeing them as potential harassers. Employers may hide behind this persona, as illustrated by the following remark from a respondent:

One day my boss, who I respect very much, touched my hand and then my hair. I screamed. He then said: "What's the matter? You are like my daughter". He never touched me again. I think he was testing how I would react and my reaction made him treat me like a daughter. He takes care of me and recently asked the 
management to give me a raise. All the other secretaries are jealous of me and started rumors about me and my boss. He is a very good man and when he was sick I visited him in hospital and gave him flowers. His wife does not like me.

The contradictions in this case illustrate not only that employers use their father-figure image as an excuse for physical contact, but also that young women (who are exposed to very few men apart from fathers, brothers, and relatives) may have difficulty identifying harassment and could become attracted to men they work with. Most often, the attraction is innocent and usually takes the form of admiration or respect.

Finally, young women are conditioned to see themselves as the vulnerable sex who must guard their chastity, which necessitates their taking preventive measures. For example, some young women claim that they applied for jobs where they did not trust the employer or co-workers and refused the employment opportunity as a result. It is also a common belief that women in dire economic need are more exposed to harassment, as employers, upon realizing their predicament, are more likely to take advantage of them. The overwhelming attitude among the young women is relief that their own families will not put them in such situations no matter how dire their economic needs are. Protecting women's sexual reputations, therefore, seems to function as a reinforcement of their economic and psychological dependence on their families. Finally, young women assert their readiness to leave their jobs at the vaguest reference to their sexuality by employers or colleagues. For example, a young woman left her assembly-line job in a textile workshop after four years of employment because a male supervisor made advances to one of her colleagues. In solidarity with her friend, the woman quit her job in order to denounce the employer and to protect herself from possible advances. The actions of both women were also viewed as a public statement of their honorable behavior should anyone start gossiping about them.

The pre-occupation with maintaining young women's sexual reputations, and, indeed young women's concerns regarding their reputations, have resulted in rather rigid male boss/female worker relations in the workplace: It is necessary for employers to act like fathers and young women to act like daughters and for young women and employers alike to constantly prove their innocence. ${ }^{11}$.Within this context it is male co-workers who remain unaccountable for their behavior and therefore pose the real threat. To minimize the threat of harassment by male co-workers, employers resort to spatial segregation as well as division of labor.

It should be noted that young women's fears of sexual harassment seem to be somewhat out of proportion to its actual occurrence. Young working women are constantly exposed to accounts of unknown women who are taken advantage of in unknown workplaces (we had no way of asserting whether such accounts were true or not). Nonetheless, for young working women in Amman, who are at a stage in their 
lives where chastity is paramount, the term sexual harassment, broadly identified with physical or verbal abuse, needs to be redefined. Women are vulnerable to the threat of sexual harassment, or even gossip about it: It has far-reaching implications for the reputation of young women and their families. The result is a fear of victimization that could be just as damaging as actually experiencing harassment.

\section{Family honor, employment and young women's public behavior}

The increasing public visibility of young women is bringing the subject of family honor in Amman to the forefront of family relations. The fact that so many women are working and, consequently, are outside the immediate control of male kin during large parts of the day causes anxiety. Young women's employment not only involves relinquishing some male control within the home; there is also increasing emphasis on men as the public protectors of their female kin. Because single employed adulthood is a new phenomenon, women's public behavior, considered the primary threat to family honor, is continuously monitored.

Male kin react differently, depending on the household, to the possibility of losing control over the behavior of their female relatives and being publicly disgraced. The most stringent responses to women who breach the family honor code are termed "honor crimes." 12 Victims of these crimes are young women suspected of illicit sexual relations outside of marriage; the only way to cleanse and restore the family honor is to kill the woman who has damaged it. From 1986 to 1996, the annual average number of such crimes in Jordan was $23 .{ }^{13}$ For Jordan, which has low crime rates, this also amounts to 31 percent of all reported murders in the country in the past decade (See Husseini 1994). It is alarming to note that the number of such crimes seems to be increasing gradually (Husseini 1994).

While this extreme reaction generally receives negative media coverage and public disdain, it reflects the current crisis among Jordanian families relating to changing gender and generation relations. These crimes tend to occur in poor rural or urban areas and against young women (Mansur 1996). It appears that economic need and high male unemployment result in men viewing young women's work as a threat to the male power base. In urban areas, crowded housing conditions expose families to increased contact with people outside the immediate family, which puts increased pressure on male family members to protect their female kin. As a result, women's behavior is increasingly scrutinized in order to avoid the tarnishing of family honor. Middle- and upper-income families, meanwhile, perhaps feel less need to publicly assert their honorable family reputation because of their established economic prestige. Such families may also have better means to disguise incidents of sexual harassment when they occur. The result is that the utmost scrutiny is given to the public behavior of families in which young women's work is necessary for survival. 
As far as the interviewees are concerned, honor crimes happen to other women and not themselves. Young women are conditioned to be horrified by the occurrence of honor crimes. Therefore, those who are intent on gaining certain freedoms are adamant about preserving their chaste sexual reputations. Ironically, the few gains that young women have made in renegotiating gender roles within their families have increased the significance of their public behavior. Women currently living as single employed adults, an unrecognized life stage within the traditional familial patriarchy, need to abide by a strict moral code in order to maintain or expand their new life opportunities, such as employment.

\section{Conclusion}

This paper has highlighted the fact that gender and age place different household members in different positions in the labor market. Within this context it is significant that daughters are not replicating their mothers' early age at marriage and limited workforce participation.

Compared to other family members, young women have the highest education levels but, compared with male family members, lower earnings. The increasing labor force participation of young women seems to be the result of two factors: (1) their high human capital, which facilitates their entry into the labor force; and (2) their low wages, which ensure that the status quo of the male provider ideology is not threatened.

Young women's employment is having an impact on gender and generation hierarchies: Accommodations are being made internally within households, resulting in female education and access to employment. Male family members, however, need to publicly ensure their authority over female kin. In some instances, this results in new forms of control over young working women, while in others it involves a re-assertion of old forms. New forms of control include putting limitations and conditions on young women's education and work. Re-assertion of old forms of control include heightened emphasis on family honor and female chastity. Single employed adulthood may have expanded young women's opportunities and aspirations, but it has not brought with it a significant re-distribution of power relations or gender divisions in society at large.

Young women's work has placed some women in a position where they can participate in negotiating the circumstances that make their new roles acceptable for normative gendered behavior and expectations. Although the re-negotiation of power is problematic, the seeds for "self differentiation" were present among some of the women interviewed.

In some ways these renegotiations of gender and generation hierarchies in Amman are themselves signals that at personal, relational, and societal levels change is obvious enough to cause concern and consternation in the relations of some families. It is clear that this new generation of working women will face more pressure in the future. In the long term, however, once these hierarchical boundaries have been renegotiated at the 
parental level, a re-negotiation at the spousal level may occur once these young women are married.

Finally, perhaps one of the more important conclusions here is the complexity of the relationship between women's employment and their increased social and economic autonomy, and how the greatest changes for women workers are more likely to occur within the home rather than at the workplace or through political change (Moore 1988: 111). Thus, the centrality of the family in the elaboration and enforcement of male and female behavior cannot be underestimated.

\section{References}

Abu-Lughod, Lila. 1993. Writing Women's Worlds: Bedouin Stories. Berkeley, CA: University of California Press.

Bisharat, Leila and Hisham Zagha. 1986. Health and Population in Squatter Areas of Amman: A Reassessment After Five Years of Upgrading. Amman, Jordan: Urban Development Department.

Bruce, Judith and Daisy H. Dwyer. 1988. A Home Divided: Women and Income in the Third World. Stanford, CA: Stanford University Press.

Chant, Sylvia. 1991. Women and Survival in Mexican Cities: Perspectives on Gender, Labour Markets and Low Income Households. Manchester, UK: Manchester University Press.

Department of Statistics. 1991. Employment, Unemployment, and Poverty Survey. Amman, Jordan: Department of Statistics.

Department of Statistics. 1999. Women and Men in Jordan: A Statistical Portrait. Amman, Jordan: Department of Statistics.

Husseini, Rana. 1994. "Murder in the name of honor," Jordan Times, 6-7 October.

Kabeer, Naila. 1995. "Necessary, sufficient or irrelevant? Wages and intra-household power relations in urban Bangladesh." Working Paper 25. Brighton, UK: Institute of Development Studies.

Mansur, Youssef. 1996. "Crimes in the name of honour or poverty?" Jordan Times, 23 September.

Moore, Henrietta. 1988. Feminism and Anthropology, Cambridge, UK: Polity Press. 
Oakley, Ann. 1987. "Gender and generation: The life and times of Adam and Eve," in Patricia Allatt, Teresa Keil, Alan Bryman, and Bill By the way (eds.), Women and the

Life Cycle: Transitions and Turning Points. Houndsmills, UK: Macmillan Press, pp. 13-32.

Sawalha, Aseel. 1993. "Familial relations and survival strategies of femaleheaded households in Amman, Jordan," paper presented at the Arab Family Seminar organised by UNICEF: Amman, Jordan.

Shami, Seteney and Lucine Taminian. 1989. "Reproductive behaviour and child care in a squatter area in Amman,” Regional Paper. Cairo, Egypt: Population Council.

Stichter, Sharon. 1990. "Women, employment and the family: Current debates," in Sharon Stichter and Jane Parpart (eds.) Women, Employment and the Family in the International Division of Labor. Basingstoke, UK: Macmillan Press. 